\title{
A Dialectical Definition of Conservatism
}

\author{
JAMES ALEXANDER
}

\begin{abstract}
Conservatism is now often said to be a disposition. Against definitions of conservatism as a disposition, critics say that it is also an ideology, and against any such abstract definitions, that it is a historical entity. But no one has yet indicated how these criticisms can be used to improve the definition of conservatism. Here I argue that the dispositional understanding of conservatism, while not wrong in itself, is only the first and simplest element in what has to be an extended or dialectical definition of conservatism. This article is a statement of such a definition.
\end{abstract}

1.

In this paper I want to offer a philosophical argument which will delineate the nature of conservatism. This argument will not be minimal, or analytical, in form: for I think such an argument would do an injustice to what is, in the end, a political disposition, a political movement, a political ideology. It will be an argument that attempts to do some justice not only to the history of conservatism but also to the contradictions in the meaning of conservatism. The argument will begin in the next section, after I make some preliminary comments in this section about the current state of thinking on the subject.

Most writers who write about conservatism - historians, journalists, political scientists - simply collect instances of it, and refuse to think further. But recently there has been a revival of something more ambitious. Martin Beckstein has recently argued that it is possible to find a principle that unites all forms of conservatism. In saying this, he is returning to, and attempting to clarify, Michael Oakeshott's famous definition of conservatism from the 1950s. Beckstein's claim, in short, is that conservatism is, as Oakeshott claimed it was, the disposition to hold onto the status quo: with the important qualification, introduced by Beckstein, that it is not enough to defend the status quo unconsciously or accidentally: one 


\section{James Alexander}

must do so out of some definite conviction that the status quo should be defended. ${ }^{1}$

Being truly conservative means to aim for the conservation of established institutions out of conviction and not happenstance; it means to have a presumption in favour of the given rather than a presumption in disfavour of the untried; to attach a value to the status quo because it is the status quo rather than disvalue change because it is change; and to act on an imperative of preservation because the desirability of continuity is supposed, not because the utility of innovation is doubted.

This is a meaningful distinction in theory, but really one must wonder whether it has much significance in practice. Could we ever distinguish the two? Surely under criticism the negative conservatism would soon become a positive conservatism. For instance, I might not want to admit change out of a basic fear of change; but if someone were to ask me to explain, as would be likely in a political situation, why anyone else should take my view seriously, I would have to do a bit of work to come up with something a bit more persuasive about why change would not be a good idea and why resisting change should be taken up by others. Then I would be a conservative in Beckstein's sense. So perhaps Beckstein's refinement of Oakeshott is too fine. But that is a matter of nuance. There is a far more forceful objection to Beckstein's argument. Joseph Femia points to this in his critical reply to Beckstein's article. While admitting that Beckstein may have captured something in the nature of conservatism, Femia comments that Beckstein has failed to show why we should think there is any relation between having a 'conservative disposition' and having a 'conservative ideology'. ${ }^{2}$ There are four varieties of conservatism sketched here by Beckstein and Femia. Let me try to make their positions clear by referring to four formal claims which we might consider conservative. Beckstein says that anyone who says the following might be conservative in some sense but is not a 'true conservative':

A: 'I want to hold onto the status quo because I fear change.'

To be a true conservative, according to Beckstein, a true conservative has to say the following:

1 Martin Beckstein, 'What Does It Take to be a True Conservative?', Global Discourse 5 (2015), 4-21.

2 Joseph V. Femia, 'Identifying True Conservatives: A Reply to Beckstein', Global Discourse 5 (2015), 22-23. 


\section{A Dialectical Definition of Conservatism}

B: 'I want to hold onto the status quo out of a positive conviction about its value.'

Femia disagrees with Beckstein because he thinks more has to be said about what this 'positive conviction' is. The two following claims are versions of $\mathrm{B}$, but Femia in effect suggests that we have to distinguish them. For Femia, anyone who said the following would not be a conservative:

C: 'I want to hold onto the status quo out of a positive conviction about the value of the status quo which, by the way, is, in this case, a socialist conviction.'

For Beckstein, such a claim would be that of a 'true conservative'. Doubtless, anyone who were to say $\mathrm{C}$ would have a conservative disposition of some sort; but having a conservative justification for it would be another thing entirely. A conservative policy or ideology is lacking. For Femia, B could only be a conservative claim in a meaningful political sense if something further were said to avoid saying C. Therefore:

D: 'I want to hold onto the status quo out of a positive conviction about its value, and this, by the way, is a distinctively conservative conviction, thereby making me conservative and not something else.'

Femia makes an important criticism here. In fact, he points to the problem of all problems in understanding conservatism. This is 'What makes a conviction a distinctively conservative conviction?'

I think this is a genuine conundrum. I also think that theories of the sort proposed by Beckstein are of interest because they set the problem to one side in order to achieve something like philosophical clarity about conservatism. My own view is that serious consideration of conservatism must abandon such exact philosophical clarity - in the sense of a minimal or analytical clarity which does not do justice to the difficulties of the subject. By this I do not mean we should abandon argument, but that we should attempt to recognise the significance of historical realities for the subject as well as the significance of philosophical clarity. Femia has shown where the difficulty lies with a one-sided philosophical view. But no one has yet suggested how the difficulty can be overcome. In this paper I shall argue that Beckstein's, or Oakeshott's, type of theory cannot be taken to be an entire theory of conservatism. It can only be considered an element of such a theory: a part of such a theory but not the whole; in fact, no more than the first moment of a dialectical definition of 


\section{James Alexander}

conservatism. It is only if we discover such a definition of conservatism that the difficulty can be overcome.

A few years ago I wrote an article, 'The Contradictions of Conservatism', in which I worked through what some of the most suggestive writers in the last century or so had said about conservatism. ${ }^{3}$ In that article I attempted a full characterisation of conservatism, even to the extent of recognising its contradictions. I cited all the major works written on the subject in order to do full justice to them. Perhaps the style or even the title of that article obscured the argument. So here I try again. In this article I shall proceed through my own argument rather than through quotation of other people's arguments. I shall also try to state the argument clearly so it cannot be misunderstood.

\section{2.}

Let me begin with an initial hypothesis. This is the hypothesis that:

Conservatism is holding onto what we have.

The dictionary on my computer says:

ORIGIN late Middle English: from Old French conserver (verb), conserve (noun), from Latin conservare 'to preserve,' from con'together' + servare 'to keep.'

So in its simplest, or original, meaning, 'to conserve' is to keep together or hold onto what one has. In politics 'conservatism' is the politics of standing fast and holding fast, of having and holding. It is the politics of inertia, not the politics of acceleration: and I choose the word inertia carefully, since conservatism is not about entirely resisting change: an object subject to inertia can be moving uniformly, and can be acted on by other forces.

But conservatism is not only this. And to say it is only this is an error.

This is the error Oakeshott made in his influential article, 'On Being Conservative'. ${ }^{4}$ It is likely that any discussion of conservatism will have to refer to Oakeshott for some time: for it seems to have

3 James Alexander, 'The Contradictions of Conservatism', Government and Opposition 48 (2013), 594-616.

Michael Oakeshott, 'On Being Conservative' (1956), in Michael Oakeshott, Rationalism in Politics and Other Essays (Indianapolis: Liberty Fund, 1991), 407-37. 
become the starting point of much current writing on the subject. I think Oakeshott's argument is brilliant, and not a little sly. It is remarkably persuasive: in my experience even students inclined to the progressive side of politics find it persuasive. His argument is that conservatism is only holding onto what we have: the implication being that 'what we have' is limited to what we have now, in the present. He says that conservatism is a disposition, an attitude held in the present about what is good and what is bad, and which says that what is good is holding into what we have at present. The problem with this is not that it is wrong, but that it would be wrong to think that this could exhaust the meaning of conservatism. Conservatism is more than this. The argument depends on a trick. Firstly, Oakeshott excludes from his definition anything which is not only holding onto what we have got. Secondly, and this is his particular sleight of hand, he denies that conservatism can be anything more than a disposition. In saying this, ironically, he detaches conservatism from all history: from the Conservative party, from Burke, Coleridge, Peel, Disraeli, Maine, Salisbury etc. It is not an ideology, it is not even a tradition, it is nothing to do with revolution, it has nothing to do with Burke's Reflections on the Revolution of France. Note this surprising judgement. Nothing to do with Burke, 'the father of conservatism'.

Of course, we are well aware that that the word 'conservatism' no more existed in 1790 than the word 'liberalism' did in 1690. In a strict historical sense Burke was not conservative, just as Locke, 'the father of liberalism', was not liberal. But this is not Oakeshott's point. He is not saying Burke is not conservative because he is too early, but, rather, that he is not the right sort of conservative because he is too late. Oakeshott goes back beyond Burke to the calm of the eighteenth century before the French Revolution. He says: 'It would perhaps have been more fortunate if modern conservatives had paid more attention to Hume and less to Burke'. ${ }^{5}$ The significance of this for his argument cannot be underestimated. Oakeshott not only leaves behind the century, the nineteenth, in which conservatism was named and formed into a party; he also leaves behind Burke and the revolution which provoked him to write the work which is still supposed to be the original work of conservatism. In this way Oakeshott does something very interesting for a philosopher who, as a good Cantabrigian, was so concerned with

5 Michael Oakeshott, 'Review of Russell Kirk, The Conservative Mind (1954)', in Luke O'Sullivan (ed.), The Vocabulary of a Modern European State (Exeter: Imprint Academic, 2008), 81-4, at 83. 


\section{James Alexander}

history: he abstracts conservatism from history altogether. He retreats his conservatism to the time of Hume and assumes that it can be called a 'disposition': a civilised, polite disposition to which no one could possibly take exception. But to do so is a mistake.

Or, rather, it is a mistake if we believe that Oakeshott has exhausted the subject and succeeded in telling us what conservatism is. I think that the correct way to deal with Oakeshott's argument is to say - as F.R. Leavis always used to say - 'Yes, but...'. Oakeshott is quite right as far as he goes, but he does not go very far. He tells us what conservatism is only in the simplest sense. He offers a model for what we could consider conservatism to be, if we were happy to strip back its meaning to some sort of eighteenth-century disposition. But it is not an eighteenth-century disposition; or, it is not only that: it is also a nineteenth-century party and a twentieth-century ideology.

Conservatism is holding onto what we have.

Yes, but -

So how to continue?

3.

Well, we have to recognise that we cannot simply have a model of some sort of timeless conservatism. This is possible, but it leaves us with not very much (only 'conservatism is holding onto what we have'), and, ironically, it leaves out the very consciousness of historical situation which seems to have been responsible for consciousness of conservatism in the first place. This is unsatisfactory.

What I will argue here, then, is that we have to refine the definition by adding some historical features to it. In short, I will continue by exploring a qualified version of the hypothesis, where the hypothesis is qualified by a historical fact:

Conservatism is holding onto what we have, where what we have is of the past as well as of the present, in a historical situation in which there has been a rupture with the past, and where the rupture has involved the arrival of rational, secular ideals.

Let me deal with each of these qualifying remarks one by one.

'... where what we have is of the past as well as of the present...' It is a simple matter to see why this is necessary. In short, it is because we 
live in literate cultures. So that traditions are not simply what exists in the rituals and practices we live by now, which can be handed over from one generation to the next, and which are only as long-lived as the oldest living member of a community. That would be the case in a culture without script. On the contrary, traditions are fundamentally altered by the fact that we have canons of literature in relation to which we can make our own critical and creative contributions, and by the fact that it is possible to set the truth - if we ever receive the truth - in stone, write it down for all time: in other words to have authoritative or apostolic texts, such as the Vedas, the Torah, the Dhammapada, the Bhagavad-gita, the Tao-te-Ching, the Gospels, the Qur'an, and so on. A canon is something which develops, as Newman famously argued in the nineteenth century; while the truth is the truth, one supposes, for all time, and does not develop, but cuts through history, as if from eternity. ${ }^{6}$

So 'what we have' is not simply this ritual, this poem, this song, this woman, this land, these animals, this house, it is also this literature, and through this literature, we have, in some sense, access to the rituals, poems, songs, women, lands, animals, houses of the past, and also access to the truths or insights which our ancestors were fortunate to receive. 'What we have' is not a simple thing, to which we can have a complacent Oakeshottian cottage conservatism attitude. What we have is manifold: indeed, contradictory. It involves canons which carry with them a perpetual possibility of criticism of what is had and held now, and, perhaps, involves truths which put every passing situation or belief to the question.

This might not matter very much, in itself, but it is a very significant fact, a historical fact, which Oakeshott ignores. And the significance of this fact is intensified when whatever we have from the past is seen to be in conflict with what we have in the present.

'...in a historical situation in which there has been a rupture with the past...' If the first qualification suggests that any conservatism involves a consciousness of history, of some past, then this second one is more decisive: it suggests that conservatism is not only conscious of history but emerges at a particular point in history when the past becomes suddenly far more valuable than it was before, for the reason that there has been some rupture with the past. The past is, in one sense, lost: we have lost our continuity, our traditions, our beliefs, our rituals. Instead of them we have adopted others.

6 For an elucidation of this rather abridged argument, see James Alexander, 'A Systematic Theory of Tradition', forthcoming in Fournal of the Philosophy of History. 
And so here the conservative is someone who says, 'Although we have in one sense lost the past, in another sense we still have it, because of our literary remains, and perhaps also our memories: and we have a duty to recover some element of that past: for the rupture was a mistake.' Is this clear? Conservatism, at this stage, is a consciousness not only of the past in so far as it relates to the present, but the past as it forms a contrast with the present, because, for some reason or other - which we could call revolution - the present has become severed from the past. Continuity has been severed. This rupture might be any break with the past. But in our history, and, it is important to add, in the only history in which the term 'conservatism' has any meaning, this rupture is a distinctive one, one which is historically locatable. It is the rupture which, however we conceive it, took place in the late eighteenth and nineteenth centuries. The rupture was a rupture in consciousness, which is why it did not take place at one exact moment (though we can find symbols for it: for instance, in the fall of Bastille). And this brings us to the third qualification.

'... and where the rupture has involved the arrival of rational, secular ideals...' The decisive rupture is revolution, and not any revolution, but in particular the 'revolution' of which the French Revolution is the chief example. By this we mean a revolution which was harnessed to enlightened ideals. This revolution may occur in a moment, in which case we usually call it a revolution. But the revolution is no less decisive when it takes place gradually over a century, or many centuries, as it did in Britain, where it is usually given some other gentler name, like 'reform'. By revolution I do not mean just any change in an order. It is not simply a rupture by which one set of rituals or traditions replaces another set. It is not, for instance, the rupture by which the Roman republic became the Roman empire. Ronald Syme wrote a book in the 1930s entitled The Roman Revolution about that rupture. ${ }^{7}$ His book had an eye-catching title, but a misleading one. Syme was, like Oakeshott, engaging in a bit of trickery: he was, firstly, mocking Augustus - whom he rather impertinently called 'Octavian' throughout the book (though it was only his name for a short time: even J.B. Bury, half a century before, had more correctly called him 'Caesar') - for claiming to have restored the republic. This was a reasonable point: Augustus, or his poets, lawyers and historians, did claim that Augustus had restored the republic. But Syme also was, with a very dark irony indeed, using the modern term 'revolution' to suggest that Augustus was a

\footnotetext{
7 Ronald Syme, The Roman Revolution 2nd ed. (Oxford: Oxford University Press, 1952).
} 
sort of Robespierre or Napoleon, which was far from being the case. Yet Augustus only had the mos maiorum to go by: the religion and law and customs of Rome. Whereas everyone who was involved in the French Revolution was justifying their actions by abstract principles, enlightened ideals.

So at this stage - and I hope it is clear that this is a logical stage, and not a historical stage - the conservative is not simply conscious of some lost tradition. This is not Cicero writing in defence of the republic. Here the conservative is not writing for the sake of a particular tradition, but is writing on behalf of tradition in its entirety, for any tradition and all tradition. This is for the reason that the conservative is he who is aware that the enlightened ideals by which modern revolution was carried out are abstract. So here conservatism is opposed to ideals and abstractions, and has to find arguments by which he can defend not only particular traditions against these ideals and abstractions but also - and this is very interesting, and perhaps paradoxical - arguments by which he can defend tradition in the abstract against these ideals and abstractions. He is forced eventually into the very paradoxical game of making tradition into an ideal and abstraction so he can defend it against the ideals and abstractions which are wholly opposed to all or any traditions.

\section{4.}

Let me state the contradiction of conservatism immediately, since everything I say subsequently will be affected by it, and it is better it is understood at once rather than any misunderstanding be encouraged about where the argument is headed. The contradiction is:

Conservatism involves an acceptance of the rupture; but it also involves a denial of the rupture.

'Conservatism involves an acceptance of the rupture...' Conservatism is not only reactionary, or counter-revolutionary; it accepts the conditions which have been established since the revolution or the gradual reforms by which enlightened, secular, rational, ideals have been accepted as the criteria by which political acts ought to be justified. In England, the rise of the Conservative Party in the 1830s and 1840s was only possible once the Tory Ultras or Die-Hards - the men who wanted to overturn the Great Reform Act of 1832 - were excluded. Ever since Peel, as one commentator put it, not without some irony, the conservatism of the Conservative Party has involved the view 'that the highest virtue in politics is to resist change until 


\section{James Alexander}

change becomes inevitable, and then to concede to it with as little fuss and as much obeisance to tradition as possible'. ${ }^{8}$ If we agree with this, and only this, then we have the conservatism of Oakeshott which we could well call status quo conservatism, the conservatism of simply holding onto what we have, while conceding whatever changes are necessary. But, as should have been clear from the beginning of this argument, I do not think this is only what conservatism is.

'...but it also involves a denial of the rupture...' Conservatism is not simply Peel trying to hold the fort against Russell, while accepting that the fort has been built in a new way. For even Peel's politics came out of the 'unreformed' era. There is an old order which was worth defending, and even though it had to be surrendered as a practicable object of political activity, for the sake of the law and order which the conservative of course values, it remains a structuring set of ideals for the conservative. These ideals are, since they can be listed in any particular case - as an Englishman, I write about the English case - the ideals of monarchy and aristocracy, of institutions which bring the community into a tradition hierarchy, institutions such as the Crown, the Lords, the Commons, the Law Courts, the Church, the Universities. (The institutions would be different in a different case. But the principles would be the same, or, at least, within reach of anthropological generalisation.) The ideal of the conservative remains hierarchical, whereas the ideals of the liberals and socialists are egalitarian. The conservative both thinks that hierarchies will survive in any order, including especially the ostentatiously egalitarian orders of liberals and socialists, but also thinks that hierarchies are better able to fulfil their necessary functions in a society which recognises, maintains and to some extent rewards them through ritual, title and symbol rather than simply through wealth. This is because the rewards of ritual, title and symbol are restraints as well as rewards. The conservatives in England are the defenders of the mores maiorum of the English. This sort of conservatism is counter-revolutionary conservatism.

This ambivalence runs throughout conservatism. It accepts the rupture, and does not attempt to overturn it; yet it is committed to the ideals - the only ideals it has - of an uninterrupted, an unoverturned world, and so, vestigially, and perhaps only imaginatively, and possibly only unconsciously, holds onto the ideal of overturning the established order for the sake of return to an older one. I shall explain this at greater length by taking the two sides of conservatism

8 T.E. Utley, A Tory Seer: The Selected fournalism of T.E. Utley, eds C. Moore and S. Heffer (London: Hamish Hamilton, 1989), 87. 


\section{A Dialectical Definition of Conservatism}

in turn: first, the side which accepts the rupture, and secondly, the side which does not.

\section{5.}

Let me summarise:

Conservatism is holding onto what we have, where what we have is of the past as well as of the present, in a historical situation in which there has been a rupture with the past, and where the rupture has involved the arrival of rational, secular ideals.

Conservatism involves an acceptance of the rupture; but it also involves a denial of the rupture.

Now I want to consider the acceptance of the rupture separately. It is at this point that we have to discuss conservatism - the conservatism which was for the first time called 'conservatism' - in relation to the other political creeds which were spawned by enlightenment and revolution and which, by the 1840 s, were fairly clearly defined. These were political creeds which deliberately embraced secularism and rationalism: these were liberalism and socialism.

There is a very simple point to make about this:

Conservatism accepts the rupture, and therefore tacitly accepts the enlightened ideals which justified the rupture; however, in its practical politics, it attempts to hold onto as much of the status quo as possible, and this means opposing the parties which are in favour of a politics carried out in terms of the same enlightened ideals and which in the name of those ideals favour further reform or revolution.

It is here that conservatism is not simply a matter of 'holding onto what we have': it means opposing any politics which threaten the status quo by bringing abstract ideals to bear on it. I do not want to go too far into these ideals, but it should be obvious that I am referring to the ideals of the enlightenment: the Liberté, Égalité, Fraternité of the French, the Rights of Man of Paine, the Utilitarian Calculus of Bentham etc, and, later, the complicated historical versions of enlightened ideals which began to flourish at the time of Mill and Marx. These were concerned with history to some extent, but they were not conservative: they were influenced by the Scottish economists and historians, and thought that some understanding of history was necessary in order to understand what would happen in the future. 


\section{James Alexander}

Partly this self-consciousness amongst liberals and socialists was a consequence of doubts about revolution. Marx certainly took it as his task to explain why the French Revolution had not changed the world forever. But neither Mill nor Marx wanted to hold onto the status quo or, even worse, try to go backwards.

Now, there is something to say about this. Conservatism, here, accepts the rupture. This has a consequence. It means that its politics must always be carried out according to the assumptions of the order which follows the rupture. In other words, if the order is enlightened, secular and rational, then in order to contribute to politics, conservatism must also be enlightened, secular and rational. This means that it must accept the language of its enemies to some extent: though this does not mean it must accept their ideals. There is no need to believe in enlightened ideals, but whatever they do believe in can only be expressed politically if it is asserted in terms of those enlightened ideals, since it is a condition of being allowed to take place in modern politics that assertion is in terms of enlightened ideals. There is, therefore, on this side, a likelihood that conservatism will become entirely enlightened. The more the conservative assumes that he is committed to maintaining the status quo and making concessions only where necessary, and the more the status quo is adjusted by the more progressive parties in accordance with their enlightened ideals, the more the conservative will attempt to conserve an enlightened order. At this stage, conservatism will be nothing other than the politics of inertia, the politics of resistance followed soon after by the politics of reluctant concession. And then the old joke that the conservative holds onto to the liberal or socialists reforms of a previous generation will be true. This is the conjectural fate of the status quo conservative. But, of course, my argument is that the status quo conservative is an Oakeshottian cardboard cut-out. Such figures do exist, and the Conservative Party may be full of them (no doubt complicated by other bits of enlightened ideals which make even Conservatives think they should now reform actively), but they are operating with a rather empty and one-sided idea of conservatism.

Let me state the complication, however.

This means that conservatism may become enlightened in conserving a status quo which is itself built out of the enlightened ideals of an earlier generation of non-conservatives.

That is not all. For since, as I mentioned earlier, the conservative is aware of the complication of history, the conservative may, in opposing the ostentatiously progressive reforms of other political parties, return to the examples of politics from any time following the 
rupture. The conservative might then not be reactionary in attempting to overturn the system; but reactionary in a lesser sense, not a systematic reactionary but a reactionary of the detail, attempting to reverse some enlightened politics of, say, to choose a still obvious example, the welfare state. If the Conservative Party of 2015 were to attempt to return the state to its position in 1939 - which is of course impossible outside of a thought experiment - then it would, in principle, not be an entire overturning of the modern political system, but an overturning of one element of an enlightened politics which was established subsequent to the system. It would be a reaction within the frame of the rupture, rather than reaction against the rupture and against the system the rupture established.

'This is all very abstract, no doubt, this talk of 'rupture' and 'system'. But I think this is unavoidable, since these ideas are latent in the nature of conservatism. They structure the way conservatives think, even when they think in terms of contradictions.

As I approach the other side of the contradiction, the denial of the rupture, it is perhaps first worth alluding to a theory I developed elsewhere while reflecting on the relations between liberalism, socialism and conservatism. ${ }^{9}$ In short, I maintained that there is a dialectical relation between these three ideologies. The argument was that we can understand the major ideologies forming a circle, along with the original unenlightened condition. Let me state this schematically:

First, there was an unenlightened condition, of hierarchies, traditions, caprice, and much custom: for instance, what was called the ancien régime in France.

Then there was a rupture. The rupture in France was chaotic and it was a generation before the politics of the interrupted order settled down. In our history, the only one we have, politics settled down in the mid-nineteenth century with the formation of ideologies and parties or movements which were attached to these ideologies. Things have changed a bit since the nineteenth century, but when we are talking about the original, or major, ideologies, this is irrelevant. The three ideologies form a logical sequence:

Second, then, there was liberalism, which opposed to all the tradition and custom of the unenlightened order the requirement that all politics should be justified solely in terms of the good of the self, which was conceptualised for the first time as an

9 James Alexander, 'The Major Ideologies of Liberalism, Socialism and Conservatism', Political Studies 63 (2015). 


\section{James Alexander}

autonomous individual.

Third, there was socialism, which added to the liberal requirement the further requirement that the self be seen as constituted by its role and relation to others in society, so requiring the attention be paid not only to the legal status of the self but also its economic status.

Fourth, there was conservatism, which added to the socialist requirement the further requirement that the self be seen as constituted not only by its social existence in the present but also by its relation to those no longer living and those not yet living, so existing in a historical nexus in which it was important not to sacrifice tradition for the sake of an abstract ideal.

The point that makes this scheme fully circular is that though conservatism is here seen to be an intensification of the enlightened criterion for politics, it ends by gesturing at reverence for the old unenlightened order. So the circle is, here at least, complete.

This circle is of course nothing other than an experiment in thought: that is to say, it is possible to argue with it at almost every point. But it is thinkable. It asks everyone to see that the ideologies are dialectically related; and not only dialectically related to each other, but also to the traditional order in which enlightened ideals were nothing but fantasies, and where ideologies or movements or parties such as liberalism, socialism and conservatism did not exist because they could not exist. All the ideologies are founded on the first, liberal, principle, which is that politics should be constructed or justified in terms of the equal right of all persons to enjoy the same consideration, and, in particular, consideration in the form of liberty: that is, consideration in the form of a concession to the individual. Socialism and conservatism begin here; though, out of necessity, they think the liberal makes a mistake in stopping here: so they intensify and complicate the criterion.

The merit of the circle is that it expresses clearly what I want to express here: that conservatism is contradictory, or ambivalent. As I put it earlier, conservatism accepts the rupture with tradition; it also denies it. So now I consider the denial.

6.

When conservatism accepts the rupture, it is, in the first instance, concerned with the status quo; but then it faces the parties advocating 
further applications of enlightened ideals, and has to oppose these, so it then has to develop not only an effective way of arguing negatively against these enlightened positions, but has to find positive ways of doing so which do not contradict the enlightened nature of the entire political order. This raises many practical problems, of which many examples can be found in the history of politics of the last one hundred and fifty years in many different countries. If conservatism were only a status quo party it would be an enlightened party. But what I am arguing here - as should be obvious from the image of the circle in the last section - is that conservatism is not entirely enlightened. (And it is not entirely enlightened not simply because of inertia: though, of course, as I have said, it is a blind resistance to enlightenment at one stage of its dialectic.) It points back to an unenlightened politics. It points back to before the rupture. It may not advocate return, but it insists that what is of absolute value is to be found there and not here.

There is 'before the revolution' as opposed to here, 'after the revolution'. What I have argued so far is that conservatism, in its simplest form, is holding onto what one has. But it has followed a rupture and a rupture of a particular sort, founded on enlightened ideals. So, in its second sense, it is holding onto what one has in a situation where one has accepted the rupture, and the enlightened conditions established by the rupture, but where one attempts to resist any further extension of enlightened ideals over the body politic. This involves resisting the parties of progress, and so involves forming a party - a Conservative party by name or, if not by name, then by nature which has to use the techniques of modern politics, and perhaps even use progressive language and policies at times to achieve its ends: thus involving it in complications by which even the staunchest conservative might well be confused. But there is also a third stage, and this is the stage at which the conservative returns to the roots of his tradition (or, we might say, his imagined tradition): roots which grew before the rupture. Without some sort of traditional roots conservatism lacks any absolute orientation of its own. It is simply the politics of inertia, doggedly opposed to the politics of progress and enlightened ideals (liberty, equality, fraternity etc). But if it has some sort of traditional roots, then it has an ideal. This ideal is not an abstract ideal, taken from the books of philosophers, but is the ideal of an interrupted continuity, the ideal of the age which was in full possession of its traditions before the rupture.

Let me state this:

Conservatism denies the rupture: it denies the enlightened ideals which justified the establishment of the order following the 


\section{James Alexander}

rupture, and seeks to return, in imagination, but also as a practical orientation, to the unenlightened ideals of the older order.

Here, perhaps, we should only talk of specifics. Each culture which has its own word for 'conservatism' will have its own rupture and its own traditions which were sundered by the rupture. But generalisations are possible. Anthropologically speaking, what existed before the enlightenment everywhere amounts to, I think, though of course this involves great simplification, three things:

1. sacrality,

2. hierarchy, and

3. specificity.

I have thought about these three things at some length, but do not have time to defend their choice here: I can only hope that they should seem evidently plausible candidates for what I am talking about. By sacrality I mean that there was an established cult or church, and that the entire social and political order was inseparable from the divine, so that the king was, in some sense or other, the monarch because of divine right or grace. By hierarchy I mean that there were hierarchies running from the king at the top through lords, priests, jurists, soldiers, merchants and so on down to the peasants: and that these were embedded in the system, so the social order was the same thing as these structures of hierarchy. The only external means of assessing the order was the one supplied by religion. By specificity I mean that every institution originated out of a specific response to a specific problem. There were, no doubt, attempts to impose uniformity, whether under the banner of sacrality, or because of the decision of someone higher up in the hierarchy, but there was never an attempt to impose a deliberate uniformity on the body politic in terms of some abstract or universal principle.

It follows that the enlightened order contains the opposite three things:

1. secularity.

2. equality, and

3. generality.

In this sense, then, conservatism is not only opposed to the progressive or enlightened policies now, in so far as they threaten the established order; it is also opposed to the progressive or enlightened ideals of secularity, equality and generality in toto, and in favour of a restoration, were it ever possible - which it might never be - of sacrality, hierarchy and specificity. I wrote in my essay on 'The 
Contradictions of Conservatism' that the symbol of this sort of reactionary-radical conservatism might be the divine monarch. I am not so sure that conservatism should be reduced to something as particular as this (even though the idea of a divine monarch seems fairly ubiquitous around the world until the eighteenth century, and even cast a shadow over the Greek polis and Renaissance respublica): nonetheless, it could be taken as a symbol for such old orders.

So:

This means that conservatism is at this stage wholly opposed to the enlightened ideals of secularity, equality and generality and holds onto the unenlightened ideals of sacrality, hierarchy and specificity - however difficult it is to apply these in an enlightened political order.

7.

The argument of this paper is that conservatism can only be defined if we define it dialectically, in such a way that we can incorporate its contradictions into one definition. As should be evident, I think this is possible, and here it is, adding the numbers $1,2,3$ to make absolutely clear the different stages of the dialectic:

1. Conservatism is holding onto what we have, where what we have is of the past as well as of the present, in a historical situation in which there has been a rupture with the past, and where the rupture has involved the arrival of rational, secular ideals.

Conservatism involves 2. an acceptance of the rupture; but 3. it also involves a denial of the rupture.

2. Conservatism accepts the rupture, and therefore tacitly accepts the enlightened ideals which justified the rupture; however, in its practical politics, it attempts to hold onto as much of the status quo as possible, and this means opposing the parties which are in favour of a politics carried out in terms of the same enlightened ideals and which in the name of those ideals favour further reform or revolution.

This means that conservatism may become enlightened in conserving $a$ status quo which is itself built out of the enlightened ideals of an earlier generation of non-conservatives.

3. Conservatism denies the rupture: it denies the enlightened ideals which justified the establishment of the order following the 


\section{James Alexander}

rupture, and seeks to return, in imagination, but also as a practical orientation, to the unenlightened ideals of the older order.

This means that conservatism is at this stage wholly opposed to the enlightened ideals of secularity, equality and generality and holds onto the unenlightened ideals of sacrality, hierarchy and specificity - however difficult it is to apply these in an enlightened political order.

This is, I hope, a refutation of the Oakeshottian, or minimal, definition of conservatism which, it should be obvious, narrows down conservatism to the first line only of this dialectical definition. Note that this is a refutation not by contradiction, but a refutation by extension - to include contradiction. It is perhaps worth saying again that I am not arguing that Oakeshott is wrong: only that his view of conservatism was minimal to a fault. It can be used, and is used, by advocates of conservatism who want to make conservatism sound like the most natural thing in the world - which, of course, at the first stage of its dialectic, it is - but apart from this rather sly, apparently neutral but actually polemical, use, it cannot be justified. It excludes too much. And it makes conservatism unexceptional. It might be of political advantage to make an objectionable position seem less objectionable than it really is, but it is of little philosophical value. A minimal definition simply does not enable us to understand conservatism.

JAMES ALEXANDER (jalexand@bilkent.edu.tr) teaches in the Department of Political Science, Bilkent University, Ankara. His recent publications include 'Notes Towards a Definition of Politics', Philosophy (2014), 'A Sketch of a System of Theory and Practice', Political Studies Review (2015) and 'Three Major Ideologies of Liberalism, Socialism and Conservatism', Political Studies (2015). 